\title{
Predictors of transient congenital primary hypothyroidism: data from the German registry for congenital hypothyroidism (AQUAPE “HypoDok")
}

\author{
Nicola Matejek ${ }^{1}$ (D) Sascha R. Tittel ${ }^{2} \cdot$ Holger Haberland $^{3} \cdot$ Tilman Rohrer $^{4} \cdot$ Eva-Maria Busemann $^{5} \cdot$ Norbert Jorch $^{6}$. \\ Karl-Otfried Schwab ${ }^{7} \cdot$ Joachim Wölfle ${ }^{8} \cdot$ Reinhard W. Holl $^{2} \cdot$ Markus Bettendorf $^{1}$
}

Received: 4 December 2020 / Revised: 9 March 2021 / Accepted: 12 March 2021 / Published online: 25 March 2021

(C) The Author(s) 2021

\begin{abstract}
Neonatal screening for congenital primary hypothyroidism $(\mathrm{CH})$ may not distinguish between transient $(\mathrm{TCH})$ and permanent dysfunction $(\mathrm{PCH})$, causing potential overtreatment and concerns in affected families. To specify the indication for interruption of therapy, we analysed the German registry "HypoDok" for infants with $\mathrm{CH}$, which oversees 1625 patients from 49 participating centres in Germany and Austria from 1997 until today. A total of 357 patients with a thyroid gland in loco typico were identified and retrospectively grouped according to cessation (TCH, $n=24)$ or continuation ( $\mathrm{PCH}, n=333$ ) of L-thyroxine ( $\mathrm{L}^{-\mathrm{T}_{4}}$ ) treatment at 2 years of age. The receiver operating characteristic (ROC) analysis was performed to identify cutoffs predicting TCH by screening TSH concentrations and L- $\mathrm{T}_{4}$ dosages. Gestational ages, birth weights and prevalence of associated malformations were comparable in both groups. The cutoff screening TSH concentration was $73 \mathrm{mU} / \mathrm{L}$. The cutoff daily L- $\mathrm{T}_{4}$ dosage at 1 year was $3.1 \mu \mathrm{g} / \mathrm{kg}$ (90\% sensitivity, 63\% specificity; $36 \mu \mathrm{g} /$ day) and at 2 years of age $2.95 \mu \mathrm{g} / \mathrm{kg}$ (91\% sensitivity, $59 \%$ specificity; $40 \mu \mathrm{g} /$ day). At 2 years of age, specificity ( $71 \%$ ) increased when both of these parameters were considered together.

Conclusion: The decision to continue or cease $\mathrm{L}_{-} \mathrm{T}_{4}$ treatment at 2 years of age in $\mathrm{CH}$ patients diagnosed in neonatal screening may be based on their screening TSH concentrations and individual $\mathrm{L}^{-\mathrm{T}_{4}}$ dosages at 1 and 2 years of age. Thus, TCH and PCH may be distinguished; overtreatment avoided; and affected families reassured.
\end{abstract}

Communicated by Peter de Winter

Nicola Matejek

nmatejek@t-online.de

Sascha R. Tittel

sascha.tittel@uni-ulm.de

Holger Haberland

holger.haberland@sana-kl.de

Tilman Rohrer

tilman.rohrer@uks.eu

Eva-Maria Busemann

e.busemann@kindermvz.de

Norbert Jorch

norbert.Jorch@evkb.de

Karl-Otfried Schwab

karl.otfried.schwab@uniklinik-freiburg.de

Joachim Wölfle

Joachim.Woelfle@uk-erlangen.de

Reinhard W. Holl

reinhard.holl@uni-ulm.de
Markus Bettendorf

markus.bettendorf@med.uni-heidelberg.de

1 Division of Paediatric Endocrinology and Diabetes, Department of Paediatrics, University Children's Hospital Heidelberg, Im Neuenheimer Feld 430, 69120 Heidelberg, Germany

2 Central Institute for Biomedical Technology, Institute for Epidemiology and Medical Biometry, University of Ulm, Ulm, Germany

3 Social-Paediatric Centre, Sana-Hospital Lichtenberg, Berlin, Germany

4 Department of Paediatrics, University Hospital Homburg-Saar, Homburg, Germany

5 Catholic Children's Hospital Wilhelmstift, Hamburg, Germany

6 Department of Paediatrics, Evangelical Hospital Bethel, Bielefeld, Germany

7 Division of Paediatric Endocrinology and Diabetes, University Hospital Freiburg, Freiburg, Germany

8 Department of Paediatrics, University Hospital Erlangen, Erlangen, Germany 


\section{What is Known:}

- The course of congenital primary hypothyroidism may be transient, causing potential overtreatment.

- The dose of L-thyroxine at 1 or 2 years of age may predict a transient course of primary congenital hypothyroidism.

What is New:

- TSH screening concentration and L-thyroxine dosages at 1 and 2 years of age represent reliable predictors for transient congenital primary hypothyroidism with higher sensitivity and specificity when considered together in order to select eligible patients who qualify for treatment withdrawal.

Keywords Congenital primary hypothyroidism - Prediction - Transient congenital primary hypothyroidism · Permanent congenital primary hypothyroidism

\section{Introduction}

Congenital primary hypothyroidism $(\mathrm{CH})$ is suspected in neonatal screening when capillary TSH concentrations are elevated (> $15 \mathrm{mU} / \mathrm{L}$ in Germany). The diagnosis is confirmed by measuring venous $\mathrm{TSH}$ and $\mathrm{fT}_{4}$ concentrations before the start of treatment [1]. Not all infants with confirmed $\mathrm{CH}$ necessarily receive lifelong $\mathrm{L}_{\mathrm{T}} \mathrm{T}_{4}$ treatment. Transient congenital hypothyroidism $(\mathrm{TCH})$ occurs in up to $35 \%$ of children with $\mathrm{CH}$ [2]. Lowering the threshold screening TSH concentrations for diagnosing $\mathrm{CH}$ may suggest an increased prevalence, overtreatment and impaired outcome in children that only have transient or mild hypothyroidism [3]. Gene mutations of DUOX2 and TSH-R have been described in cases with mild transient hypothyroidism [4-7]. National and international guidelines recommend confirming $\mathrm{CH}$ after the second birthday in case an unequivocal diagnosis has not been established during the neonatal period. L$\mathrm{T}_{4}$ treatment is then paused for 4 to 6 weeks in order to assess endogenous thyroid function. Earlier withdrawal is discussed when transient elevations of neonatal TSH concentrations are likely and there is impending overtreatment [7-10]. Paediatric endocrinologists tend to conduct therapy in the first 2 years of life in order to avoid defects in the myelinisation of the central nervous system and to assure normal neurodevelopmental outcomes. A re-evaluation of thyroid function is indicated if the thyroid gland is developed normally and elevated TSH serum levels are not observed or there has been no need to adjust the dosage of $\mathrm{L}-\mathrm{T}_{4}$ during the course of treatment.

However, standard recommendations for interruption of treatment are lacking [11].

We analysed data from the German registry of $\mathrm{CH}$ in order to determine whether screening and serum TSH concentrations and $\mathrm{L}-\mathrm{T}_{4}$ dosages at 1 and 2 years of age are sufficient parameters to anticipate a transient nature of thyroid dysfunction warranting its re-evaluation.

\section{Methods}

"HypoDok" is a prospective documentation software for $\mathrm{CH}$ supported by the German Society of Paediatric Endocrinology and Diabetes (DGKED), with contributions from 49 participating centres in Germany and Austria currently including 1625 patients. The inclusion criteria were the availability of screening TSH concentrations ( $\mathrm{mU} / \mathrm{L}$ ), a thyroid gland in loco typico, visualised by ultrasound, and the $\mathrm{L}-\mathrm{T}_{4}$ dosages $(\mu \mathrm{g} / \mathrm{kg} /$ day, $\mu \mathrm{g} /$ day) at diagnosis and at 1 and/or 2 years of age, respectively. The end of $\mathrm{L}-\mathrm{T}_{4}$ treatment was documented by checking a corresponding box on the date of withdrawal. The following items were extracted from the registry: $\mathrm{L}^{-\mathrm{T}_{4}}$ dosages at 6 months of age, weeks of gestation, birth weight (g), Apgar-Score, age at measurement of screening TSH and of serum TSH, serum TSH $(\mathrm{mU} / \mathrm{L})$ and $\mathrm{fT}_{4}(\mathrm{ng} / \mathrm{dL})$ concentrations at confirmation, as well as relevant maternal and patient's history (selection options: yes/no): gender male, maternal hypothyroidism, maternal treatment with $\mathrm{L}_{-} \mathrm{T}_{4}$ during pregnancy, hyperthyroidism, anti-thyroid drugs (ATD) during pregnancy, iodine medication in pregnancy and delivery, diagnosis of Trisomy 21 and dopamine treatment of the neonate. Additional diagnoses or malformations captured as free text documentation were also considered in the analyses. The height $(\mathrm{cm})$ and body mass index $\left(\mathrm{kg} / \mathrm{m}^{2}\right)$ expressed as standard deviation scores (SDS) [12] at the age of 2 years, the $\mathrm{L}-\mathrm{T}_{4}$ withdrawal period of 4 to 6 weeks and the results of psychomotor testing at the age of 2 years were extracted. $\mathrm{L}_{-} \mathrm{T}_{4}$ dosage changes were collected from each visit. The screening TSH concentrations were measured in dry-blood spots by the regional neonatal screening laboratories in $\mathrm{mU} / \mathrm{L}$. The serum $\mathrm{TSH}(\mathrm{mU} / \mathrm{L})$ and $\mathrm{fT}_{4}(\mathrm{ng} / \mathrm{dL})$ concentrations were measured in the laboratory of the respective centre for paediatric endocrinology. A total of 357 patients treated in 37 German centres were eligible and were grouped according to continuation of $\mathrm{L}-\mathrm{T}_{4}$ beyond the 2 nd year of life ( $\mathrm{PCH}$ ) or cessation (TCH) of $\mathrm{L}-\mathrm{T}_{4}$ treatment within the first 2 years of life.

Statistics Descriptive data were presented as the median and interquartile range for continuous values and percentage for binomial/categorical values. Wilcoxon's rank sum test was used to compare continuous variables between groups, while nominal variables were analysed by chi-squared test. The results were considered significant at $p<0.05$. The receiver operating characteristic (ROC) analysis was performed to 
identify cutoffs predicting TCH by screening TSH concentrations and $\mathrm{L}_{-} \mathrm{T}_{4}$ dosages $(\mu \mathrm{g} / \mathrm{kg} /$ day and $\mu \mathrm{g} / \mathrm{day})$ at 6 month and 1 and 2 years of age, respectively. We used SAS 9.4 (SAS Inc., Cary, NC, USA) and PROC LOGISTIC to calculate predicted probabilities of the patients to belong either to the $\mathrm{TCH}$ or $\mathrm{PCH}$ group, as well as their sensitivity and specificity based on the respective screening TSH concentration or $\mathrm{L}^{-\mathrm{T}_{4}}$ dosage. The optimal cutoff for each parameter was calculated by maximising the Youden index [13]. Using linear regression made differences of screening TSH between patients with and without $\mathrm{L}-\mathrm{T}_{4}$ withdrawal period, means are presented as least square means with $95 \%$ confidence interval.

\section{Results}

A total of 357 infants with congenital primary hypothyroidism met the inclusion criteria (Fig. 1). They were grouped retrospectively as PCH $(n=333)$ and TCH $(n=24)$ (Table 1). All patients with TCH terminated therapy after 2 years of age (24/ 24). $95.2 \%$ of patients with $\mathrm{PCH}$ temporarily paused $\mathrm{L}-\mathrm{T}_{4}$ treatment for 4 to 6 weeks $(n=111,33 \%)$ and had to continue the treatment afterwards and/or required an increase of L- $\mathrm{T}_{4}$ dosage during the treatment course $(n=316,95 \%)$. Screening TSH concentrations tended to be lower in neonates with TCH $(55.8 \mathrm{mU} / \mathrm{L})$ than in those with PCH $(150.0 \mathrm{mU} / \mathrm{L}, p=0.06)$, whereas serum $\mathrm{TSH}$ and $\mathrm{fT}_{4}$ concentrations were similar at confirmation of the diagnosis (Table 2). Neonatal screening was done at 3 days of age in both groups and the confirmation of the diagnosis at $11(\mathrm{PCH})$ and 13.5 days of age $(\mathrm{TCH}$; Table 2), respectively. $\mathrm{L}^{-\mathrm{T}_{4}}$ dosages at start of therapy in $\mathrm{PCH}$ and in $\mathrm{TCH}$ were comparable $(p=1.0)$. $\mathrm{L}^{-\mathrm{T}_{4}}$ dosages per kilogramme body weight at 6 months of age were similar, and receiver operating characteristic calculation revealed 27 $\mu \mathrm{g} /$ day as predicting cutoff for TCH (sensitivity $77 \%$, specificity $54 \%$ ). At 1 year of age, the $\mathrm{L}^{-\mathrm{T}_{4}}$ dosages were significantly higher in $\mathrm{PCH}(4.52 \mu \mathrm{g} / \mathrm{kg} /$ day, total dose $45 \mu \mathrm{g} /$ day $)$ than in TCH $(2.96 \mu \mathrm{g} / \mathrm{kg} /$ day, $p<0.01 ; 30 \mu \mathrm{g} /$ day, $p<0.01)$, and were also higher at 2 years of age in $\mathrm{PCH}(4.03 \mu \mathrm{g} / \mathrm{kg} /$ day, $50 \mu \mathrm{g} /$ day $)$ than in TCH $(2.5 \mu \mathrm{g} / \mathrm{kg} / \mathrm{day}, p<0.01 ; 37 \mu \mathrm{g} /$ day, $p<0.01$ ) (Table 2).

Infants with a $\mathrm{L}-\mathrm{T}_{4}$ withdrawal period had significant lower screening TSH: $142.6 \mathrm{mU} / \mathrm{L}(119.2-166)$ vs. $186.2 \mathrm{mU} / \mathrm{L}$ $(159-213.4, p=0.02)$, shown by linear regression analysis (Table 3).

The cutoff screening TSH concentration by ROC was 73 $\mathrm{mU} / \mathrm{L}$ (Fig. 2a). The cutoff $\mathrm{L}-\mathrm{T}_{4}$ dosage at 1 year of age was $3.1 \mu \mathrm{g} / \mathrm{kg} /$ day (Fig. $2 \mathrm{~b}$ ) and $2.95 \mu \mathrm{g} / \mathrm{kg} /$ day after 2 years (Fig. 2c) (Table 4, A). The $\mathrm{L}_{-} \mathrm{T}_{4}$ dosage with $99 \%$ sensitivity was $2.0 \mu \mathrm{g} / \mathrm{kg} /$ day $(20 \mu \mathrm{g} /$ day $)$ and $6.3 \mu \mathrm{g} / \mathrm{kg} /$ day $(60 \mu \mathrm{g} /$ day $)$ with $96 \%$ specificity at 1 year of age. At 2 years of age, the $\mathrm{L}-\mathrm{T}_{4}$ dosage of $2.0 \mu \mathrm{g} / \mathrm{kg} /$ day ( $25 \mu \mathrm{g} /$ day) was $99 \%$ sensitive for $\mathrm{TCH}$ and $5.0 \mu \mathrm{g} / \mathrm{kg} /$ day $(55 \mu \mathrm{g} /$ day) was $96 \%$ specific for PCH (Table 4, A).

In a subgroup with screening TSH concentration below 73 $\mathrm{mU} / \mathrm{L}(n=109)$, the proportion of TCH $(16 \%)$ was twice as
Table 1 Demographic characteristics and medical history of patients at diagnosis: patients were grouped as permanent $\mathrm{CH}(\mathrm{PCH} ; n=333)$ or transient $\mathrm{CH}(\mathrm{TCH} ; n=24)$. Variables are presented as median and interquartile range $(\mathrm{A})$ or prevalence $(\% ; \mathrm{B})$

\begin{tabular}{|c|c|c|c|c|c|c|c|c|}
\hline \multirow[b]{2}{*}{ A } & \multicolumn{3}{|l|}{$\mathrm{PCH}$} & \multicolumn{5}{|c|}{$\mathrm{TCH}$} \\
\hline & & & & & & & & \\
\hline Variable & $n$ & Median & $\begin{array}{l}\text { Interquartile } \\
\text { range }\end{array}$ & $n$ & Median & $\begin{array}{l}\text { Interquartile } \\
\text { range }\end{array}$ & & $p$ \\
\hline Weeks of gestation & 333 & 40 & $38-41$ & 24 & 40 & $37-40$ & & 1.0 \\
\hline Birth weight (g) & 325 & 3420 & $3060-3800$ & 22 & 3380 & $2920-3850$ & & 1.0 \\
\hline APGAR-score & 326 & 10 & $7-10$ & 22 & 10 & $9-10$ & & 1.0 \\
\hline BMI $\left(\mathrm{kg} / \mathrm{m}^{2}\right)$ at 2 years & 301 & 16.6 & $15.6-17.5$ & 22 & 16 & $14.7-16.5$ & & 0.8 \\
\hline BMI-SDS at 2 years & 301 & 0.4 & $0.3-1.0$ & 22 & 0.0 & $-1.1-0.4$ & & 0.7 \\
\hline Height-SDS at 2 years & 301 & 0.1 & $-0.6-0.8$ & 23 & 0.0 & $-0.6-0.5$ & & 1.0 \\
\hline \multicolumn{9}{|l|}{ B } \\
\hline Variable & $n$ & & $\begin{array}{c}\text { Prevalence } \\
(\%)\end{array}$ & & $n$ & $\begin{array}{l}\text { Prevalence } \\
(\%)\end{array}$ & & $p$ \\
\hline Weeks of gestation $<36$ & 322 & & 5.6 & - & 24 & 12.5 & - & 1.0 \\
\hline Male gender & 333 & & 35.1 & - & 24 & 50 & - & 1.0 \\
\hline Trisomy 21 & 333 & & 1.2 & - & 24 & 4.2 & - & 1.0 \\
\hline Dopamine therapy & 333 & & 0.9 & - & 24 & 8.3 & - & 0.07 \\
\hline ATD in pregnancy & 101 & & 2 & - & 11 & 18.2 & - & 0.1 \\
\hline $\mathrm{L}-\mathrm{T}_{4}$ withdrawal period & 211 & & 52.6 & - & 24 & 100 & - & $<0.01$ \\
\hline $\begin{array}{l}\mathrm{L}-\mathrm{T}_{4} \text { withdrawal period a./o. } \\
\mathrm{L}-\mathrm{T}_{4} \text { dosage increase }\end{array}$ & 333 & & 95.2 & - & 24 & 100 & - & 1.0 \\
\hline Developmental test: normal & 141 & & 89 & - & 8 & 100 & - & 1.0 \\
\hline
\end{tabular}


Table 2 Screening TSH (mU/L), confirmation serum TSH (mU/L), serum $\mathrm{fT}_{4}(\mathrm{ng} / \mathrm{mL})$, age at neonatal screening and confirmation (days) and dosages of $\mathrm{L}-\mathrm{T}_{4}$ at diagnosis, at the age of 6 months and 1 and 2 years in patients with permanent $\mathrm{CH}(\mathrm{PCH}, n=273)$ and transient $\mathrm{CH}$ (TCH, $n$ $=23$ ). Data are given as median with interquartile range; $p<0.05$ was considered significantly different by $\chi^{2}$ test

\begin{tabular}{|c|c|c|c|c|c|c|c|}
\hline \multirow[b]{2}{*}{ Variable } & \multicolumn{3}{|c|}{$\mathrm{PCH}$} & \multicolumn{3}{|c|}{$\mathrm{TCH}$} & \multirow[b]{2}{*}{$p$} \\
\hline & $n$ & Median & Interquartile range & $n$ & Median & Interquartile range & \\
\hline Screening TSH (mU/L) & 333 & 150 & $62-237$ & 24 & 55.8 & $32.5-136$ & 0.06 \\
\hline Age at neonatal screening & 305 & 3 & $2-5$ & 24 & 3 & $2-8.5$ & 1.0 \\
\hline Age at confirmation diagnosis & 333 & 11 & $6-20$ & 24 & 13.5 & $10.5-18$ & 1.0 \\
\hline Confirmation TSH (mU/L) & 257 & 118 & $62-227$ & 23 & 100 & $42-169$ & 1.0 \\
\hline Serum $\mathrm{fT}_{4}(\mathrm{ng} / \mathrm{dL})$ & 275 & 1.16 & $0.5-2.33$ & 21 & 0.96 & $0.4-1.4$ & 1.0 \\
\hline $\mathrm{L}-\mathrm{T}_{4}$ dosage at diagnosis $(\mu \mathrm{g})$ & 333 & 50 & $44-50$ & 24 & 50 & $29-50$ & 1.0 \\
\hline $\mathrm{L}-\mathrm{T}_{4}$ dosage at diagnosis $(\mu \mathrm{g} / \mathrm{kg})$ & 328 & 13.2 & $10-15$ & 23 & 12.5 & $10-14$ & 1.0 \\
\hline $\mathrm{L}-\mathrm{T}_{4}$ dosage at 6 months $(\mu \mathrm{g})$ & 157 & 38 & $30-50$ & 13 & 25 & $25-38$ & 0.4 \\
\hline $\mathrm{L}-\mathrm{T}_{4}$ dosage at 6 months $(\mu \mathrm{g} / \mathrm{kg})$ & 153 & 4.74 & $3.8-5.76$ & 13 & 4.47 & $3.25-5$ & 1.0 \\
\hline $\mathrm{L}-\mathrm{T}_{4}$ dosage at 1 year $(\mu \mathrm{g})$ & 307 & 45 & $38-50$ & 24 & 30 & $25-42$ & $<0.01$ \\
\hline $\mathrm{L}-\mathrm{T}_{4}$ dosage at 1 year $(\mu \mathrm{g} / \mathrm{kg})$ & 306 & 4.52 & $3.8-5.2$ & 24 & 2.96 & $2.3-4.6$ & $<0.01$ \\
\hline $\mathrm{L}^{-\mathrm{T}_{4}}$ dosage at 2 years $(\mu \mathrm{g})$ & 302 & 50 & $44-60$ & 23 & 37 & $25-50$ & $<0.01$ \\
\hline $\mathrm{L}-\mathrm{T}_{4}$ dosage at 2 years $(\mu \mathrm{g} / \mathrm{kg})$ & 301 & 4.03 & $3.6-4.74$ & 22 & 2.5 & $1.95-3.66$ & $<0.01$ \\
\hline
\end{tabular}

high as in the total cohort (PCH, $n=94$ vs. TCH, $n=15$ ). The total $\mathrm{L}-\mathrm{T}_{4}$ dosage at the age of 1 year $(27.5 \mu \mathrm{g} / \mathrm{day}, 2.9 \mu \mathrm{g} / \mathrm{kg} /$ day) (Table 4, B; Fig. 2d) and at the age of 2 years ( $38 \mu \mathrm{g} /$ day, $2.96 \mu \mathrm{g} / \mathrm{kg} /$ day) (Table 4, B; Fig. 2e) predicted a transient $\mathrm{CH}$ course with a slightly lower sensitivity at 1 year and similar sensitivity at 2 years with more specificity (71\%). Predicting $\mathrm{L}^{-\mathrm{T}_{4}}$ dosages with highest sensitivity and specificity were slightly higher for TCH $(2.2 \mu \mathrm{g} / \mathrm{kg} /$ day $)$ and for PCH $(6.6$ $\mu \mathrm{g} / \mathrm{kg} /$ day) at 1 year of age in this subgroup compared to the overall group. The $\mathrm{L}-\mathrm{T}_{4}$ dosage with the highest sensitivity for $\mathrm{TCH}$ at 2 years of age is lower than in the entire group (1.85 $\mu \mathrm{g} / \mathrm{kg} /$ day), but the total daily L- $\mathrm{T}_{4}$ dosage is identical, as well as the dosage for the highest specificity. Similar to the overall group, we suggest a $\mathrm{TCH}$ predicting $\mathrm{L}^{-\mathrm{T}_{4}}$ dosage of 27.5 $\mu \mathrm{g} / \mathrm{kg} /$ day (sensitivity $62 \%$ and specificity $70 \%$ ) at 6 months of age.

The demographic characteristics of patients are listed in Table 1, B. Maternal hypothyroidism and treatment with L$\mathrm{T}_{4}$ during pregnancy were similar in both groups as well as the number of infants with other congenital malformations (data not shown). Exposure to iodine medication during pregnancy or delivery was comparable in both groups (data not shown). Neonates with $\mathrm{TCH}$ were more frequently treated with dopamine than those with PCH $(8.3 \%$ vs. $0.9 \%, p=0.07)$ and mothers of neonates with $\mathrm{TCH}$ were more often treated with $\operatorname{ATD}(p=0.1)$. An increase of the $\mathrm{L}_{-} \mathrm{T}_{4}$ dosage was required in almost all of $\mathrm{PCH}$ patients (Table 1, B) while $\mathrm{L}^{-\mathrm{T}_{4}}$ withdrawal was only carried out in one-third of $\mathrm{PCH}$ patients.

At 2 years of age, median heights and BMI of all patients with TCH and PCH were similar $(p=1.0, p=0.8)$ (Table 1 , A). The results of developmental tests were documented in $141 / 333 \mathrm{PCH}$ and in $8 / 24 \mathrm{TCH}$ patients and revealed normal results in $89 \%$ and $100 \%(p=1.0)$ of patients, respectively.

\section{Discussion}

In this study, we assessed screening and serum TSH concentrations and dosages of $\mathrm{L}-\mathrm{T}_{4}$ at 6 months and 1 and 2 years of age in infants with $\mathrm{CH}$ and a eutopic thyroid gland registered

Fig. 1 Selection of eligible patients according to the inclusion criteria: screening TSH concentrations, a eutopic thyroid gland visualised by ultrasound and the $\mathrm{L}-\mathrm{T}_{4}$ dosages at diagnosis and at 1 and 2 years of age

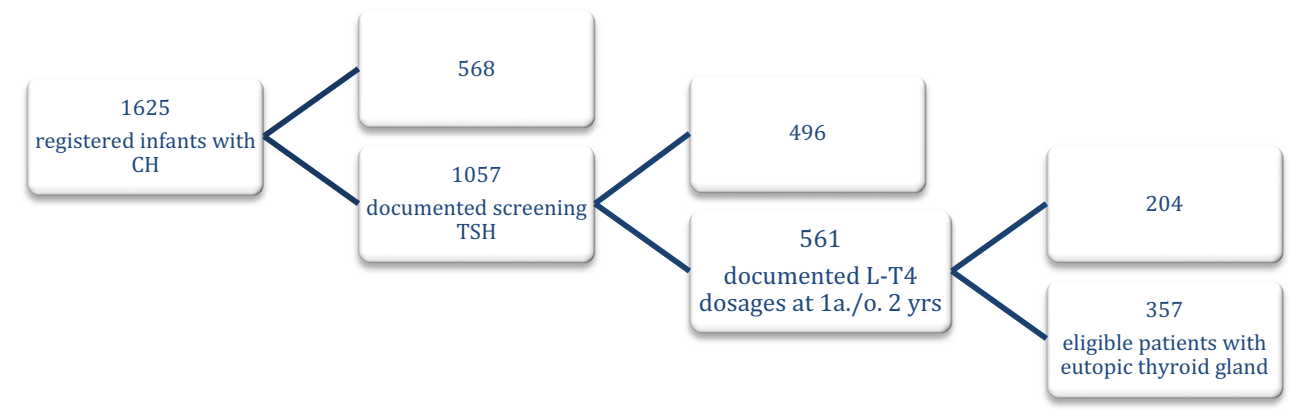


Table 3 Subgroup analyses in patients with screening TSH $<$ $73 \mathrm{mU} / \mathrm{L}(n=109)$ : $\mathrm{L}-\mathrm{T}_{4}$ dosages at the age of 6 months and 1 and 2 years in patients with permanent $\mathrm{CH}(\mathrm{PCH}, n=94)$ and transient $\mathrm{CH}(\mathrm{TCH}, n=15)$

\begin{tabular}{|c|c|c|c|c|c|c|c|}
\hline \multirow[b]{2}{*}{ Variable } & \multicolumn{3}{|c|}{$\mathrm{PCH}$} & \multicolumn{3}{|c|}{$\mathrm{TCH}$} & \multirow[b]{2}{*}{$p$} \\
\hline & $n$ & Median & $\begin{array}{l}\text { Interquartile } \\
\text { range }\end{array}$ & $n$ & Median & $\begin{array}{l}\text { Interquartile } \\
\text { range }\end{array}$ & \\
\hline $\mathrm{L}-\mathrm{T}_{4}$ dose at 6 months $(\mu \mathrm{g})$ & 45 & 35 & $25-38$ & 10 & 25 & $25-35$ & 0.35 \\
\hline $\mathrm{L}-\mathrm{T}_{4}$ dose at 6 months $(\mu \mathrm{g} / \mathrm{kg})$ & 45 & 4.1 & $3.4-5.4$ & 10 & 3.6 & $3.2-4.5$ & 0.5 \\
\hline $\mathrm{L}-\mathrm{T}_{4}$ dose at 1 year $(\mu \mathrm{g})$ & 86 & 40 & $37-50$ & 15 & 25 & $25-44$ & 0.02 \\
\hline $\mathrm{L}-\mathrm{T}_{4}$ dose at 1 year $(\mu \mathrm{g} / \mathrm{kg})$ & 86 & 4.4 & $3.5-5.2$ & 15 & 2.8 & $2.3-4.9$ & 0.04 \\
\hline $\mathrm{L}-\mathrm{T}_{4}$ dose at 2 years $(\mu \mathrm{g})$ & 82 & 50 & $38-50$ & 14 & 25 & $25-40$ & $<0.01$ \\
\hline $\mathrm{L}-\mathrm{T}_{4}$ dose at 2 years $(\mu \mathrm{g} / \mathrm{kg})$ & 82 & 3.9 & $3.2-4.3$ & 14 & 2.3 & $1.95-3.7$ & 0.01 \\
\hline $\begin{array}{l}\mathrm{L}-\mathrm{T}_{4} \text { withdrawal period a./o. } \mathrm{L}-\mathrm{T}_{4} \\
\text { dosage increase }\end{array}$ & 94 & 94 & - & 15 & 100 & - & 0.5 \\
\hline
\end{tabular}

Detection of milder forms of $\mathrm{CH}$ has refocused attention on the initial intent of neonatal screening, namely prevention of mental retardation. Lowering the threshold of TSH concentrations in the neonatal screening prompted an increase of positive $\mathrm{CH}$ results [15] and more cases with mild hypothyroidism and

Table 4 Cutoff concentrations predicting TCH by screening TSH concentration and dosages of L-T 4 at the ages of 1 and 2 years (A). Subgroup analyses in patients with screening TSH $<73 \mathrm{mU} / \mathrm{L}$ ( $\mathrm{PCH} n=94, \mathrm{TCH} n=15$ ) (B)

\begin{tabular}{|c|c|c|c|}
\hline & Cutoff & Sensitivity $\%$ & Specificity $\%$ \\
\hline \multicolumn{4}{|l|}{ A } \\
\hline Screening TSH & $73 \mathrm{mU} / \mathrm{L}$ & 72 & 63 \\
\hline $\mathrm{L}-\mathrm{T}_{4}$ at 1 year $\mu \mathrm{g} / \mathrm{kg} /$ day & 3.1 & 90 & 63 \\
\hline$\mu \mathrm{g} /$ day & 36 & 85 & 54 \\
\hline $\mathrm{L}-\mathrm{T}_{4}$ at 1 year $\mu \mathrm{g} / \mathrm{kg} /$ day & 2.0 & 99 & 4 \\
\hline$\mu \mathrm{g} /$ day & 20 & 99 & 8 \\
\hline $\mathrm{L}-\mathrm{T}_{4}$ at 1 year $\mu \mathrm{g} / \mathrm{kg} /$ day & 6.3 & 4 & 96 \\
\hline$\mu \mathrm{g} /$ day & 60 & 10 & 96 \\
\hline $\mathrm{L}-\mathrm{T}_{4}$ at 2 years $\mu \mathrm{g} / \mathrm{kg} /$ day & 2.95 & 91 & 59 \\
\hline$\mu \mathrm{g} /$ day & 40 & 84 & 65 \\
\hline $\mathrm{L}-\mathrm{T}_{4}$ at 2 years $\mu \mathrm{g} / \mathrm{kg} /$ day & 2.0 & 99 & 27 \\
\hline$\mu \mathrm{g} /$ day & 25 & 100 & 13 \\
\hline $\mathrm{L}-\mathrm{T}_{4}$ at 2 years $\mu \mathrm{g} / \mathrm{kg} /$ day & 5.0 & 18 & 96 \\
\hline$\mu \mathrm{g} /$ day & 55 & 31 & 96 \\
\hline \multicolumn{4}{|l|}{ B } \\
\hline $\mathrm{L}-\mathrm{T}_{4}$ at 1 year $\mu \mathrm{g} / \mathrm{kg} /$ day & 2.9 & 85 & 60 \\
\hline$\mu \mathrm{g} /$ day & 27.5 & 86 & 60 \\
\hline $\mathrm{L}-\mathrm{T}_{4}$ at 1 year $\mu \mathrm{g} / \mathrm{kg} /$ day & 2.2 & 99 & 13 \\
\hline$\mu \mathrm{g} /$ day & 20 & 99 & 7 \\
\hline $\mathrm{L}-\mathrm{T}_{4}$ at 1 year $\mu \mathrm{g} / \mathrm{kg} /$ day & 6.6 & 2 & 93 \\
\hline$\mu \mathrm{g} /$ day & 60 & 8 & 100 \\
\hline $\mathrm{L}-\mathrm{T}_{4}$ at 2 years $\mu \mathrm{g} / \mathrm{kg} /$ day & 2.96 & 81 & 71 \\
\hline$\mu \mathrm{g} /$ day & 38 & 83 & 64 \\
\hline $\mathrm{L}-\mathrm{T}_{4}$ at 2 years $\mu \mathrm{g} / \mathrm{kg} /$ day & 1.85 & 99 & 21 \\
\hline$\mu \mathrm{g} /$ day & 25 & 99 & 7 \\
\hline $\mathrm{L}-\mathrm{T}_{4}$ at 2 years $\mu \mathrm{g} / \mathrm{kg} /$ day & 6.3 & 11 & 100 \\
\hline$\mu \mathrm{g} /$ day & 72.5 & 18 & 100 \\
\hline
\end{tabular}



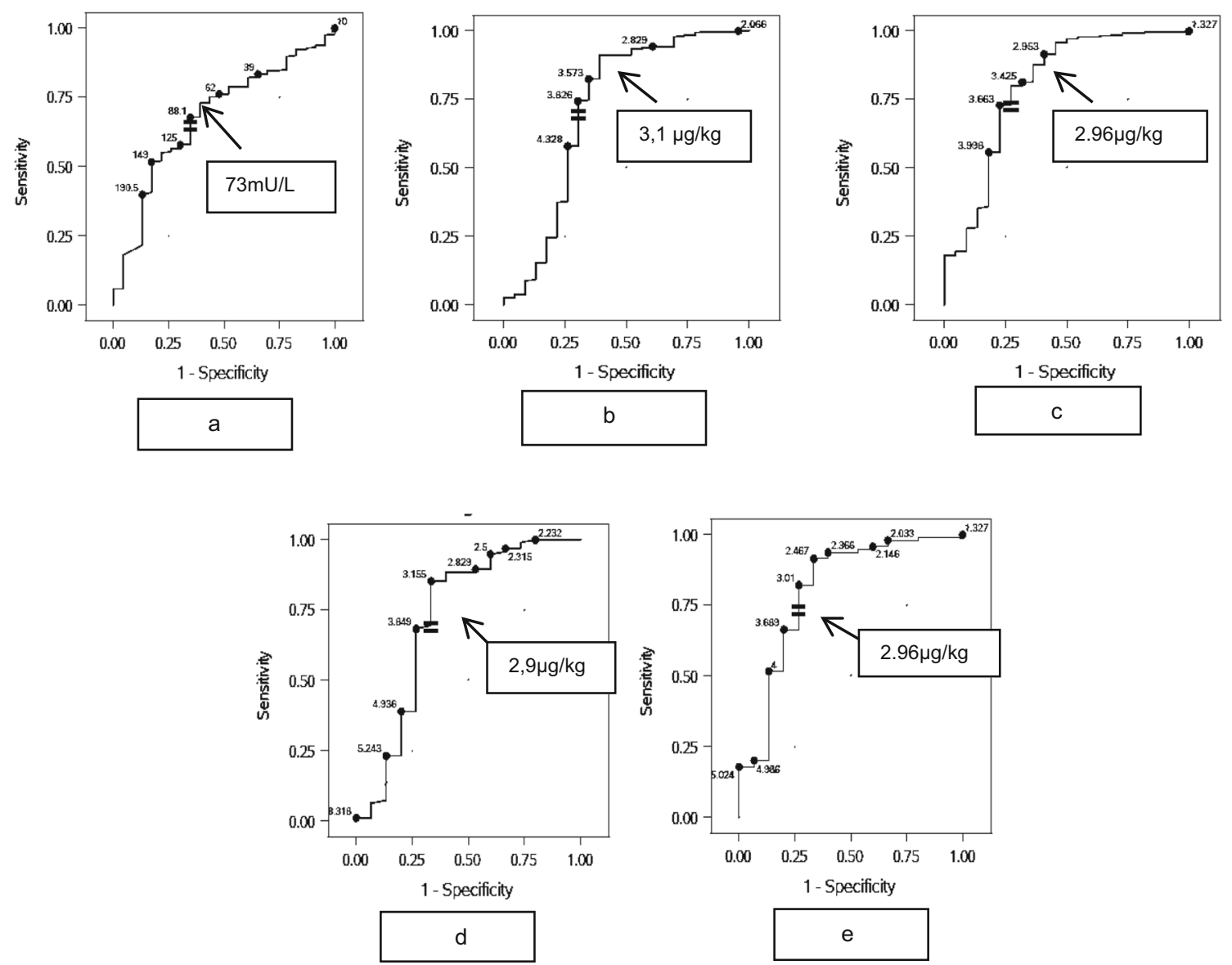

Fig. 2 Receiver operating characteristic (ROC) for screening TSH concentration (a), dosages of L-T 4 at the age of 1 (b) and 2 (c) years in patients with $\mathrm{CH}$ predicting TCH. Subgroup analyses in patients with screening TSH $<73 \mathrm{mU} / \mathrm{L}$ : dosages of $\mathrm{L}^{-\mathrm{T}_{4}}$ at the ages of 1 (d) and 2 (e) years

transient courses were detected $[15,16]$. The decrease of the TSH threshold in all likelihood increased the laboratory and economic burden of neonatal screening programs as well as the concern of affected families, but it is not clear whether these patients actually benefit from early detection and treatment [17-19]. A lower TSH threshold in the neonate screening in other countries outside of Germany (> $15 \mathrm{mU} / \mathrm{L}$ ) could explain the higher percentage of TCH in other studies $[19,20]$. Retrospective studies showed that neonates with a mildly elevated screening TSH $(<15$ and $<20$ $\mathrm{mU} / \mathrm{L})$ are at risk for permanent hypothyroidism $[3,9,19]$. As up to $35 \%$ of patients may be affected by $\mathrm{TCH}$, defining these criteria seems worthwhile. Our analyses revealed a rate of $7 \%$ for TCH, which is lower than reported in previous studies $[2,8$, $9,16]$. In order not to treat infants with TCH unnecessarily for too long, a safe approach for infants with TCH should be defined in guidelines [1, 20, 21]. Current guidelines recommend reevaluation of the thyroid axis after 2 years of age and after completion of CNS myelination $[1,20]$ but concise evaluation criteria for this are lacking so far [22, 23]. The current recommendations of the 2020 consensus congenital hypothyroidism guideline update may raise the prevalence of $\mathrm{TCH}$, as treatment of hyperthyreotropinemia is recommended from the second week of life [21]. The differentiation of isolated hyperthyreotropinemia and primary hypothyroidism in neonates proves challenging [23].

Reliable predictors represent the basis for the recommendation to withdraw $L-\mathrm{T}_{4}$ in infancy when the diagnosis of hypothyroidism remains uncertain for neonates with a normally located thyroid gland.

Serum TSH concentrations at diagnosis were similar for all patients with TCH and $\mathrm{PCH}$, which confirms previous analyses on discrimination between TCH and PCH in children with a eutopic thyroid gland $[24,25]$. Neonatal screening is scheduled for a narrow period of time within 14 days of age $[1,21]$ and is conducted in 11 German screening laboratories. Therefore, age-dependent variations of serum TSH concentrations are expected to have a minor effect as in the vast majority of cases the confirmation of diagnosis was done within the first 14 days of age in both groups. Serum TSH concentrations may be further affected by daytime, gender [26] and specific assay modalities such as range and sensitivity [27].

Treatment of mothers with iodine, anti-thyroid drugs or dopamine medication in neonates frequently causes $\mathrm{TCH}$, because these drugs suppress thyroid function in the neonate temporarily $[26,27]$. In our study, in the TCH group, dopamine medication was more often used in the neonatal period as expected. The 
prevalence of TCH and PCH was similar in our analyses when mothers were treated with anti-thyroid drugs during pregnancy, but insufficiently treated Morbus Basedow is a rare disease during pregnancy (prevalence 1:100.000-1:310.000 neonates) [28]. The proportion of preterm infants in our analysis is comparable to the overall premature birth rate in Germany [29]. Premature neonates have a higher risk of $\mathrm{TCH}$, mediated by immaturity and medications during the intensive care period [19]. Thus, these cases will not to be reported to "HypoDok", if temporary treatment is expected.

$\mathrm{L}-\mathrm{T}_{4}$ treatment dosages at various time points during the first 3 years have been reported to discriminate TCH from $\mathrm{PCH}[2,7-10,16]$. Based on these parameters, the decision to withdraw $\mathrm{L}-\mathrm{T}_{4}$ treatment in infancy in order to re-evaluate endogenous thyroid function may be made.

When calculating the exact $\mathrm{L}-\mathrm{T}_{4}$ dosage per $\mathrm{kg}$ body weight, the available galenic preparations and their strengths should be considered; the smallest incremental change in $\mathrm{L}-\mathrm{T}_{4}$ dosage possible to prescribe is $5 \mu \mathrm{g} / \mathrm{drop}$ or $2 \mu \mathrm{g} / 0.1 \mathrm{~mL}$ liquid. Our results add to those of other groups who examined infants with $\mathrm{CH}$ and a eutopic thyroid gland $[2,7,8,16]$. Our findings suggest the predicting cutoff for $\mathrm{TCH}$ at 2 years of age is the $\mathrm{L}-\mathrm{T}_{4}$ dosage of $2.0 \mu \mathrm{g} / \mathrm{kg} /$ day and accordingly 25 $\mu \mathrm{g} / \mathrm{day}$, whereas results of other study groups ranged from $0.94[8]$ to $2.8 \mu \mathrm{g} / \mathrm{kg} /$ day [16].

It is important to note that, based on our results, the screening TSH cutoff of $73 \mathrm{mU} / \mathrm{L}$ may be used as a discriminatory parameter, but this does not apply to the confirmatory TSH measurement. Confirmatory TSH concentration measured at around 11-14 days of age did not differ between the TCH and $\mathrm{PCH}$ group (Table 2).

The screening TSH may aid as a valid parameter for predicting $\mathrm{TCH}$, as the sensitivity for screening $\mathrm{TSH} \leq 73$ $\mathrm{mU} / \mathrm{L}$ shown by ROC is reliable and the impact of low screening TSH to decide on $\mathrm{L}-\mathrm{T}_{4}$ withdrawal period is significant. Considering the $\mathrm{L}-\mathrm{T}_{4}$ dosages at 1 and 2 years of age in infants with $\mathrm{CH}$ and a eutopic thyroid gland can make more reliable prediction of $\mathrm{TCH}$ and $\mathrm{PCH}$. We are the first to report that a combination of both parameters increases the sensitivity and specificity of predicting either $\mathrm{TCH}$ or $\mathrm{PCH}$.

This study has limitations due to the retrospective study design, the limited number of patients resulting from the limited overall $\mathrm{CH}$ patient coverage of "HypoDok" and the potential selection bias of patients included in the optional registry by the treating physicians. The optional participation in the "HypoDok" registry results in incomplete documentation and reduces the number of eligible patients. A register analysis is not allowed to publish cutoff values with the highest sensitivity predicting TCH and with the highest specificity predicting $\mathrm{PCH}$, because the anonymity of patient data may be compromised. Therefore, we present values with reliability over $95 \%$ or median values of $100 \%$. However, a large population could be analysed, reflecting routine $\mathrm{CH}$ patient care in Germany. Thus, our results can provide a basis for the selection of those $\mathrm{CH}$ patients who qualify for treatment cessation in infancy. Overtreatment can influence the physical, neurological or behavioural development of young infants with lifelong consequences and may increase uncertainties for both families and physicians $[15,30]$. Future studies aimed to confirm these parameters as prognostic markers for TCH should be planned prospectively and molecular analyses should be included.

Abbreviations ATD, Anti-thyroid drugs; BMI, Body mass index; $\mathrm{CH}$, Congenital primary hypothyroidism; DGKED, German Society of Paediatric Endocrinology and Diabetes; $\mathrm{fT}_{4}$, Free serum thyroxine; HypoDok, Specialised prospective documentation software for $\mathrm{CH}$; L$\mathrm{T}_{4}$, L-Thyroxine; PCH, Permanent congenital primary hypothyroidism; ROC, Receiver operating characteristic; SDS, Standard deviation score; $\mathrm{TCH}$, Transient congenital primary hypothyroidism; TSH, Thyroid-stimulating hormone

Authors' Contributions Nicola Matejek and Markus Bettendorf contributed to the study concept and design, the analysis and interpretation of data and the preparation of the manuscript. Sascha R. Tittel and Reinhard W. Holl contributed to the study concept and design, the analysis and interpretation of data and the revision of the manuscript. They administered and managed the registry HypoDok. Joachim Wölfle, Tilman Rohrer and Karl-Otfried Schwab contributed to the analysis and interpretation of data and to the revision of the manuscript. Holger Haberland, Eva-Maria Busemann and Norbert Jorch contributed to the revision of the manuscript. All authors participated in the acquisition of data and approved the final version of the manuscript.

Funding Open Access funding enabled and organized by Projekt DEAL.

Availability of data and material All data relevant to this study are included in the manuscript.

Code availability SAS 9.4 (SAS Inc., Cary, NC, USA) and PROC LOGISTIC.

\section{Declarations}

Ethics approval The AQUAPE HypoDok initiative was approved by a central ethics committee at the University of Magdeburg, and each centre complied with local data management guidelines. The local caregivers obtained parental written consent. All data was collected during routine care.

Consent to participate Written consent has been obtained from the parents/caregiver of each patient after full explanation of the purpose and nature of all procedures used.

Consent for publication Not applicable.

Conflict of interest The authors declare no competing interests.

Open Access This article is licensed under a Creative Commons Attribution 4.0 International License, which permits use, sharing, adaptation, distribution and reproduction in any medium or format, as long as you give appropriate credit to the original author(s) and the source, provide a link to the Creative Commons licence, and indicate if changes were made. The images or other third party material in this article are included 
in the article's Creative Commons licence, unless indicated otherwise in a credit line to the material. If material is not included in the article's Creative Commons licence and your intended use is not permitted by statutory regulation or exceeds the permitted use, you will need to obtain permission directly from the copyright holder. To view a copy of this licence, visit http://creativecommons.org/licenses/by/4.0/.

\section{References}

1. Krude H (2010) Diagnose, Therapie und Verlaufskontrolle der Primären, angeborenen Hypothyreose. https://www.awmf.org/ leitlinien/detail/1//027-017.html

2. Messina MF, Aversa T, Salzano G, Zirilli G, Sferlazzas C, De Luca F, Lombardo F (2015) Early discrimination between transient and permanent congenital hypothyroidism in children with eutopic gland. Horm Res Paediatr 84: 159-164

3. Lain S, Trumpff C, Grosse SD, Olivieri A, van Vliet G (2017) Are lower TSH cutoffs in neonatal screening for congenital hypothyroidism warranted? Eur J Endocrinol; 177(5):D1-D12

4. De Deken X (2019) DUOX defects and their roles in congenital hypothyroidism. Methods Mol Biol 1982:667-693

5. Fu C (2015) Mutation screening of DUOX2 in Chinese patients with congenital hypothyroidism. J Endocrinol Invest 38(11): 1219-1224

6. Peters C, Nicholas A, Schoenmakers E, Lyons G, Langham S, Serra EG, Sebire NJ, Muzza M, Fugazzola L, Schoenmakers N (2019) DUOX2/DUOXA2 mutation frequently cause congenital hypothyroidism that evades detection on newborn screening in the united kingdom. Thyroid 29(6):790-797

7. Rabbiosi S, Vigone MC, Cortinovis F, Zamproni I, Fugazzaloa L, Persani L, Corbetta C, Chiumello G, Weber G (2013) Congenital hypothyroidism with eutopic thyroid gland: analysis of clinical and biochemical features at diagnosis and after re-evaluation. J Clin Endocrinol Metab 98(4):1395-1402

8. Scavone M, Carboni E, Stefanelli E, Romano G, Vero A, Giancotti L, Miniero R, Talarico V (2018) Prediction of transient or permanent congenital hypothyroidism from initial thyroid stimulating hormone levels. Indian Pediatr 55:1059-1061

9. Kanike N, Davis A, Shekhatwat PS (2017) Transient hypothyroidism in the newborn: to treat or not to treat. Transl Pediatr 17 6(4): 349-358

10. Asena M, Demiral M, Ünal E, Öcal M, Demirbilek H, Özbek MN (2020) Validity of 6th month L-thyroxine dose for differentiation of transient-permanent congenital hypothyroidism. J Clin Res Pediatr Endocrinol 12(3):275-280

11. Kemper AR, Grosse SD, Baker M, Pollock AJ, Hinton DF, Shapira $S$ (2020) Treatment discontinuation within 3 years of levothyroxine initiation among children diagnosed with congenital hypothyroidism. J Pediatr 223:136-140

12. Kromeyer-Hauschild K, Moss A, Wabitsch M (2015) Referenzwerte für den Body-Mass-Index für Kinder, Jugendliche und Erwachsene in Deutschland. Anpassung der AGA-BMIReferenz im Altersbereich von 15 bis 18 Jahren. Adipositas 9: $123-127$

13. Ruopp MD, Perkins NJ, Whitcomb BW, Schisterman EF (2008) Youden Index and optimal cou-point estimated from observations affected by a lower limit of detection. Biom J 50(3):419-430

14. Nennstiel U e.a. National Screening Report Germany (2017) https://www.screening-dgns.de/Pdf/Screeningreports/DGNSScreeningreport-d_2017.pdf
15. Krude H, Blankenstein O (2011) Treating patients not numbers: the benefit and burden of lowering TSH newborn screening cut-offs. Archives of Disease in Childhood 96:121-122

16. Cho MS, Cho GS, Park SH, Jung MH, Suh BK, Koh DG (2014) Earlier re-evaluation may be possible in pediatric patients with eutopic congenital hypothyroidism requiring lower L-thyroxine doses. Ann Pediatr Endocrinol Metabol 19:141-145

17. West R, Hong J, Derraik JG, Webster D, Heather NL (2020) Newborn screening TSH values less than $15 \mathrm{mU} / \mathrm{L}$ are not associated with long-term hypothyroidism or cognitive impairment. J Clin Endocrinol \& Metab 105(9):e3329-e3338

18. Mengreli C, Kanaka-Gantenbein C, Panagiotis G, Magiakou MA, Christakopoulou I, Giannoulia-Karantana A, Chrousos GP, DacouVoutetakis C (2010) Screening for congenital hypothyroidism: the significance of threshold limit in false-negative results. J Clin Endocrinol Metabol 95(9):4283-4290

19. Srinivasan R, Harigopal S, Turner S, Cheetham T (2012) Permanent and transient congenital hypothyroidism in preterm infants. Acta Paediatr 101:e179-e182

20. Léger J, Olivieri A, Donaldson M, Torresani T, Kurde H, van Vliet G, Polak M, Butler G (2014) European Society for Paediatric Endocrinology Consensus Guidelines on screening, diagnosis, and management of congenital hypothyroidism. J Clin Endocrinol Metab 99: 1-22

21. Congenital hypothyroidism: 2020 consensus guideline update An ENDO-EUROPEAN NETWORK (ERN) initiative endorsed by the European Society for Pediatric Endocrinology and the European Society for Endocrinology. Thyroid. 2020 Dec 3. 10.1089/thy.2020.0333. Epub anhead of print. PMID: 33272083

22. Oron T, Lazar L, Shimon BY, Tenenbaum A, Yackobovitch-Gavan M, Meyerovitch J, Philip M, Lebenthal Y (2018) Permanent vs transient congenital hypothyroidism: assessment of predictive variables. J Clin Endocrinol Metab 103(12):4428-4436

23. Lain SJ, Bentley JP, Wale V, Roberts CL, Jack M, Wilcken B, Nassar N (2016) Association between borderline neonatal thyroid-stimulating hormone concentrations and educational and developmental outcome: a population-based record-linkage study. Lancet: Diabetes and Endocrinology 4:756-765

24. Park IS, Yoon JS, So CH, Lee HS, Hwang JS (2017) Predictors of transient congenital hypothyroidism in children with eutopic thyroid gland. Ann Pediatr Endocrinol Metab 22(2)

25. Higuchi S, Hasegawa Y (2019) Levothyroxine dosages less than $2.4 \mu \mathrm{g} / \mathrm{kg} /$ day at 1 year and $1.3 \mu \mathrm{g} / \mathrm{kg} /$ day at 3 years of age may predict transient congenital hypothyroidism. Clin Pediatr Endocrinol 28(4):127-133

26. Di Dalmazi G, Assunta M, Carlucci DS, Cesidio G, Napolotano G, Patrizio C, Bucci I (2020) A detailed analysis of the factors influencing neonatal TSH: results from a 6-year congenital hypothyroidism screening program. Front Endocrinol 17 July

27. Favresse J, Burlacu MC, Maiter D, Gruson D (2018) Interferences with thyroid function immunoassays: clinical implications and detection algorithm. Endocrine reviews 39(5):830-850

28. Van der Kaay DC, Wassermann JD, Palmert MR (2016) Management of neonates born to mothers with graves disease. Pediatrics 137(4):e20151878

29. Berger R, Rath W, Abele H, Garnier Y, Kuon RJ, Maul H (2019) Reducing the risk of preterm birth by ambulatory risk factor management. Dtsch Ärzteblatt Int 160(50):858-864

30. Bongers-Schokking JJ, Resing WCM, de Rijke YB, de Ridder MA, de Muinck Keizer-Schraman SMPF (2013) Cognitive development in congenital hypothyroidism: is overtreatment a greater threat than undertreatment? J Clin Endocrinol 98(11):4499-4506

Publisher's note Springer Nature remains neutral with regard to jurisdictional claims in published maps and institutional affiliations. 